\title{
Effect of Al(III) speciation on coagulation of highly turbid water
}

\author{
Jr-Lin Lin ${ }^{\mathrm{a}}$, Chihpin Huang ${ }^{\mathrm{a}, *}$, Jill Ruhsing Pan ${ }^{\mathrm{b}}$, Dongsheng Wang ${ }^{\mathrm{c}}$ \\ ${ }^{a}$ Institute of Environment Engineering, National Chiao Tung University, 75, Po-Ai Street, Hsinchu, Taiwan \\ ${ }^{\mathrm{b}}$ Biotechnology Center, National Chung Hsing University, 250 Kuo Kuang Road, Taichung, Taiwan \\ ${ }^{\mathrm{c}}$ SKLEAC, Research Center for Eco-Environmental Sciences, CAS, P.O. Box 2871, Beijing 100085, China
}

Received 25 August 2007; received in revised form 12 January 2008; accepted 28 January 2008

Available online 10 March 2008

\begin{abstract}
In Taiwan, the turbidity of raw water for fresh water treatments can sometimes reach as high as 40000 NTU due to intensive rainfall, especially in typhoon seasons. In response, water works often apply large quantities of coagulants such as polyaluminium chloride (PACl). In this study, simulated and natural highly turbid water was coagulated with two PACls, a commercial product (PACl-1) and a laboratory product (PACl-E). The Al species distributions of PACl-1 and PACl-E under various pH conditions were determined, and the corresponding coagulation efficiency was evaluated. The PACl-E has a wider range of operational $\mathrm{pH}$, while the efficiency of PACl-1 peaks at around neutral $\mathrm{pH}$. For simulated water up to $5000 \mathrm{NTU}$, the PACl-E was superior to PACl-1 at low dosage and in the $\mathrm{pH}$ range studied. Similar results were discovered with natural water, except that when the turbidity was extremely high, the coagulation efficiency of PACl-E decreased significantly due to the presence of large amounts of organic matter. The coagulation of PACl-E was closely related to the content of polycationic aluminium $\left(\mathrm{Al}_{13}\right)$ while that of $\mathrm{PACl}-1$ was dictated by the amount of $\mathrm{Al}_{\mathrm{c}}$. The sludge from PACl-E coagulation had better dewaterability when the optimum dosage was applied. The experimental results suggest that for natural water up to $5000 \mathrm{NTU}, \mathrm{PACl}$ containing high $\mathrm{Al}_{13}$ species is recommended for coagulation. In cases when the water contains high organic matter, efficient coagulation depends upon enmeshment by amorphous aluminium hydroxide.
\end{abstract}

(C) 2008 Elsevier Ltd. All rights reserved.

Keywords: Polyaluminium chloride; Aluminium speciation; Coagulation; Turbidity

\section{Introduction}

During typhoon seasons in Taiwan, excessive upstream erosion has substantially raised the turbidity of surface waters. Consequently, the raw water turbidity for water purification is extremely high. Turbidity of the raw water at the pump station can reach over tens of thousands NTU, which can significantly handicap the water treatment plant. Researchers have explored strategies such as fullscale sludge blanket, dissolved air floatation (DAF) and two-stage filtration to treat highly turbid water (Lin et al., 2004; Kwon et al., 2004; Di Bernardo and Di Bernardo, 2006). Unfortunately, the applicable range of

\footnotetext{
* Corresponding author. Tel.: +886 3 5726463; fax: +886 35725958 .

E-mail address: cphuang@mail.nctu.edu.tw (C. Huang).
}

turbidity was substantially lower than what we have encountered in Taiwan. The highly turbid water also occurs annually in the arid zone of western China, where water treatment plants draw raw water from the Yellow River. The river water contains extremely high concentration of solids, which is carried into water treatment plants such as the Langchou water treatment plant. In response, several large pre-sedimentation tanks have been constructed prior to upstream of the conventional water treatment plant. After the sedimentation of great amounts of suspended particles, the supernatant was then delivered to the treatment plant. The coagulant was replaced by polyacrylamide in the coagulation process to enhance turbidity removal (Fang and $\mathrm{Fu}, 2004)$. Because of land scarcity in Taiwan, expansion of the sedimentation tank is beyond reach. Most waterworks in Taiwan generously apply polymers such as polyaluminium chloride $(\mathrm{PACl})$ 
in hopes of bringing down the high turbidity. In the existing facility, however, performance was limited.

Poor performance of $\mathrm{PACl}$ has been blamed on its low content of critical hydrolysis products, especially polycationic aluminium $\left(\mathrm{Al}_{13}\right) \cdot \mathrm{Al}_{13}$ is a highly charged polymeric aluminium species, $\mathrm{Al}_{13} \mathrm{O}_{4}(\mathrm{OH})_{24}^{7+}$, which is an effective agent for charge neutralization (Wang and Hsu, 1994). Studies have also confirmed that $\mathrm{Al}_{13}$ is the key to efficient coagulation of particulates and natural organic matter (NOM) by PACl (Wang et al., 2002; Gao et al., 2005; $\mathrm{Hu}$ et al., 2006). $\mathrm{PACl}$ is an intermediate product during hydrolysis, polymerization and precipitation of aluminium salts. There are different ways to produce PACl. Researchers have shown that the distribution of $\mathrm{Al}$ species in $\mathrm{PACl}$ varies according to the physical and chemical conditions during PACl production Bertsch, 1987; Bottero et al., 1987; Kloprogge et al., 1992; Qu and Liu, 2004; $\mathrm{Hu}$ et al., 2005. A PACl with over $70 \% \mathrm{Al}_{13}$ has been produced by an electrolysis process (Liu et al., 1999a). PACl containing over $90 \% \mathrm{Al}_{13}$ has also been prepared by sulfate precipitation and nitrate metathesis $\left(\mathrm{SO}_{4}^{2-} / \mathrm{Ba}^{2+}\right.$ separation method) from a pre-hydrolyzed $\mathrm{PACl}$ solution produced by alkaline titration method (Shi et al., 2007). Similar results can be achieved through separation and purification by ultra-filtration (Huang et al., 2006). In addition, the $\mathrm{pH}$ of the solution has a profound effect on $\mathrm{Al}$ speciation of $\mathrm{PACl}$ during coagulation processes, depending mainly on its $\mathrm{OH}^{-} / \mathrm{Al}$ ratio (Wang et al., 2004). Studies have shown that treatment of highly turbid water is affected by rapid mixing and humic acid content (Kan et al., 2002; Annadurai et al., 2004). However, there has been limited research investigating the effects of $\mathrm{Al}$ speciation on coagulation for highly turbid water treatments. To determine the effectiveness and optimum conditions of $\mathrm{PACl}$ on treating highly turbid water, the $\mathrm{Al}$ speciation of $\mathrm{PACl}$ in relation to the mechanism of coagulation must be examined thoroughly. In this study, experiments were carried out to investigate the effects of $\mathrm{PACl}$ speciation on coagulation efficiency for waters of different levels of turbidity. One commercial and one laboratory $\mathrm{PACl}$ product were applied to a range of highly turbid waters.

\section{Materials and methods}

\subsection{Highly turbid water samples}

The sediment for the preparation of the highly turbid water samples was collected from the Shihmen Reservoir located in Taoyuan County, Taiwan. The sediment was mixed with tap water and aerated for $1 \mathrm{~h}$, followed by settling for $30 \mathrm{~min}$. After settling, the supernatant was used as the stock solution, to which deionized water was added to prepare the highly turbid water samples with the desired turbidity. Natural highly turbid water was also collected from rivers of northern, central, and southern Taiwan during heavy rainfalls. The suspension was also settled for
$30 \mathrm{~min}$, and the supernatant was collected as the natural highly turbid water sample.

Dissolved organic carbon (DOC) was measured by total organic carbon analyzer (TOC-5000A, Shimadzu, Japan). Particle size distribution and zeta-potential were characterized by particle size analyzer (Mastersizer 2000, Malvern, UK) and laser zeta analyzer (Zetasizer nano ZS, Malvern, UK), respectively. The characteristics of the two natural water (Natural 1 and Natural 2) and one simulated water (Simulated) samples are listed in Table 1. The table indicates that the properties of the simulated water were quite similar to those of the two natural waters, except that the turbidity as well as DOC and volatile solids of Natural 2 were substantially higher.

\subsection{Coagulants}

Two $\mathrm{PACl}$ products were used in this study. Reagentgrade $\mathrm{PACl}\left(\mathrm{Al}_{2} \mathrm{O}_{3}=10 \%\right)$ was purchased from Showa Chemicals Inc., designated as PACl-1. Another PACl $\left(\mathrm{Al}_{2} \mathrm{O}_{3}=33 \%\right)$ named PACl-E, for the electrochemical process by which it is made, was received as a gift from the Research Center for Eco-environmental Sciences, Chinese Academy of Sciences in China. The $\mathrm{OH}^{-} / \mathrm{Al}$ ratios, $\gamma$, of PACl-1 and PACl-E were 1.4 and 2.1, respectively. Working solutions containing $1000 \mathrm{mg}^{-1}$ as $\mathrm{Al}$ were freshly prepared from the solutions before each test. Aluminium concentration was analyzed by inductive coupled plasma atomic emission spectrometry (ICPAES) (JY24, Jobin-Yvon, France).

\subsection{Jar tests}

Standard jar tests were conducted in one-liter beakers to evaluate coagulation efficiencies. An initial rapid mixing was conducted at $200 \mathrm{rpm}\left(\mathrm{G}=350 \mathrm{~s}^{-1}\right)$ for one min followed by a slow mixing at $30 \mathrm{rpm}\left(\mathrm{G}=25 \mathrm{~s}^{-1}\right)$ for $20 \mathrm{~min}$. Zeta-potential was measured immediately without dilution after the rapid mixing. The suspension was left undisturbed for $20 \mathrm{~min}$. After settling, the residual turbidity (RT) of the supernatant was measured.

Table 1

Characteristics of simulated and natural highly turbid water

\begin{tabular}{llll}
\hline Parameters & \multicolumn{2}{l}{ Stock water samples } & \\
\cline { 2 - 4 } & Simulated & Natural 1 & Natural 2 \\
\hline Turbidity (NTU) & - & $300-7500$ & 35000 \\
Turbidity after 30 min & $4500-5300$ & $200-6500$ & 10000 \\
$\quad$ settling (NTU) & & & \\
pH & 8.1 & $7.6-8.2$ & 8.1 \\
Zeta-potential (mV) & -22 to -18 & -21.9 to -13.8 & -18.1 \\
Size $(\mu \mathrm{m})$ & $0.8-2.2$ & $0.5-2.3$ & 2.0 \\
Alkalinity (mg 1 & $100-120$ & $70-200$ & 191 \\
$\quad$ as CaCO3) & & & \\
DOC (mg 1 & $2.0-3.0$ & $2.1-2.7$ & 8.5 \\
VS of TS $(\%)$ & 4.5 & $1.2-3.7$ & 8.3 \\
\hline
\end{tabular}




\subsection{Ferron assay}

The Ferron colorimetric method has been widely adopted to quantify aluminium species (Smith, 1971). In this study, a slightly modified version of the Ferron method was used (Wang et al., 2004). After the addition of the Ferron agent, the $\mathrm{PACl}$ sample was immediately shaken to ensure a complete reaction between the Ferron agent and Al. The aluminium species were quantified by timed absorbance at $366 \mathrm{~nm}$ with a UV-Visible Spectrometer (U3010, Hitachi, Japan). Based on the kinetics of the reactions between the aluminium species and Ferron agent, the hydrolyzed $\mathrm{Al}$ species can be categorized into three groups: $\mathrm{Al}_{\mathrm{a}}$, monomeric; $\mathrm{Al}_{\mathrm{b}}$, the polycations; and $\mathrm{Al}_{\mathrm{c}}$, the amorphous aluminium hydroxide. The absorbance in the first minute was assigned to $\mathrm{Al}_{\mathrm{a}}$, and from one min to two hours to $\mathrm{Al}_{\mathrm{b}}$. $\mathrm{Al}_{\mathrm{c}}$ was obtained by subtracting $\mathrm{Al}_{\mathrm{a}}$ and $\mathrm{Al}_{\mathrm{b}}$ from the total Al. The total aluminium concentration of the solution was maintained at $0.37 \mathrm{mM} \mathrm{Al}$ for the duration of the test.

\subsection{Aluminium-27 nuclear magnetic resonance $\left({ }^{27} \mathrm{Al} N \mathrm{NR}\right)$}

The distributions of hydrolyzed species of PACl-1 and PACl-E in solution were also determined by $500 \mathrm{MHz}$ ${ }^{27} \mathrm{Al}$ nuclear magnetic resonance (NMR) (Uniytinova500, Varian, USA). The operational parameters for the NMR analysis: spectrometer frequency, solvent, and temperature, were set at $130.246 \mathrm{MHz}, \mathrm{D}_{2} \mathrm{O}$, and $298 \mathrm{~K}$, respectively. A 5-mm sample tube (Wilmad 507-pp, SP Industries Inc., USA) containing $3 \mathrm{~mL} \mathrm{Al}$ solution and a 4.2-mm sample tube (Wilmad WGS-5BL, SP Industries Inc., USA) containing $1 \mathrm{~mL} 50 \mathrm{mM} \mathrm{Al}(\mathrm{OD})_{4}^{-}$solution were co-inserted as the internal standard. The chemical shift of $\mathrm{Al}(\mathrm{OD})_{4}^{-}$was at $80 \mathrm{ppm}$. The signals in the proximity of $0 \mathrm{ppm}, 3-4 \mathrm{ppm}$, and $62.5 \mathrm{ppm}$ represent monomeric Al $\left(\mathrm{Al}_{\mathrm{m}}\right)$, dimeric $\mathrm{Al}\left(\mathrm{Al}_{2}\right)$, and tridecamer $\mathrm{Al}_{13}$, respectively. The concentration of each species was determined by the ratio of the integrated intensity of the corresponding peak to that of $\mathrm{Al}(\mathrm{OD})_{4}^{-}$at $80 \mathrm{ppm}$. The amount of the undetectable species (denoted as $\mathrm{Al}_{\mathrm{u}}$ ) was obtained by subtracting the sum of the detected $\mathrm{Al}$ species from the total $\mathrm{Al}$ concentration.

\section{6. $p H$ effect on Al species distribution}

Solutions contained $1 \mathrm{mM} \mathrm{NaOCl}$ and $1 \mathrm{mM} \mathrm{Na}_{2} \mathrm{CO}_{3}$ to maintain the conductivity and ionic strength for each test. Various amounts of $\mathrm{NaOH}$ and $\mathrm{HCl}$ solutions were added to the solutions to maintain the final $\mathrm{pH}$. After the addition of the coagulant, the solution was stirred at $200 \mathrm{rpm}$ for one min followed by the Ferron assay. The total aluminium concentration of the solution was held at $0.2 \mathrm{mM} \mathrm{Al}$ for each $\mathrm{pH}$ condition. All the experiments were carried out at $23 \pm 1{ }^{\circ} \mathrm{C}$.

\subsection{Sludge dewatering test}

The dewaterability of the sludge from PACl-1 and PACl-E coagulation was evaluated by specific resistance to filtration (SRF) and capillary suction time (CST). The zeta potentials of PACl-1 and PACl-E sludge were also measured. Natural water samples at 1300 NTU were used to estimate the dewatering characteristics of sludge from the settled sludge after PACl-1 and PACl-E coagulation.

\section{Results and discussion}

\subsection{Al speciation of PACl-1 and PACl-E}

Al speciation of PACl-1 and PACl-E was identified by Ferron assay and ${ }^{27} \mathrm{Al}$ NMR method. The results are summarized in Table 2. By Ferron assay, the major Al species of PACl-1 were found to be monomeric $\mathrm{Al}\left(\mathrm{Al}_{\mathrm{m}}\right)$ and $\mathrm{Al}_{\mathrm{c}}$ $\left(\mathrm{Al}(\mathrm{OH})_{3}\right)$ while the majority of the $\mathrm{Al}$ species in PACl-E was found to be $\mathrm{Al}_{\mathrm{b}}$. The $\mathrm{Al}_{\mathrm{m}}$ and $\mathrm{Al}_{13}$ by ${ }^{27} \mathrm{Al}$ NMR measurement correspond to the $\mathrm{Al}_{\mathrm{a}}$ and $\mathrm{Al}_{\mathrm{b}}$, respectively. Although there was some discrepancy between the composition of $\mathrm{Al}_{\mathrm{b}}$ and $\mathrm{Al}_{13}$, both methods confirmed that PACl$\mathrm{E}$ contained much more $\mathrm{Al}_{13}$. Other studies have also indicated that $\mathrm{Al}_{13}$ can be roughly represented by $\mathrm{Al}_{\mathrm{b}}$. (Parker and Bertsch, 1992; Liu et al., 1999a; Shi et al., 2007). Therefore, the Ferron assay was used to estimate the Al speciation of $\mathrm{PACl}$ in further studies.

\section{2. $p H$ effect on turbidity removal}

Literature has indicated that $\mathrm{pH}$ change may have a significant effect on $\mathrm{PACl}$ coagulation (Wang et al., 2002; $\mathrm{Hu}$ et al, 2006). Because both turbidity and $\mathrm{pH}$ of the coagulation suspension can affect the optimum dosages of PACls, the 250 NTU water samples were used to avoid the interference of high turbidity on the coagulation $\mathrm{pH}$ effect experiments. Jar tests were performed on both simulated water and natural water without $\mathrm{pH}$ control to determine the optimum dosages of PACl-1 and PACl-E. The optimum coagulant dosages for 250 NTU simulated water by PACl-1 and PACl-E were $2.5 \mathrm{mg}^{-1}$, which were applied

Table 2

Characteristics of coagulants by Ferron assay and ${ }^{27}$ Al NMR method

\begin{tabular}{|c|c|c|c|c|c|c|c|c|}
\hline \multirow[t]{2}{*}{ Coagulant } & \multirow[t]{2}{*}{$\gamma$} & \multirow[t]{2}{*}{$\mathrm{pH}$} & \multicolumn{3}{|c|}{ Ferron assay (A1 \%) } & \multicolumn{3}{|c|}{${ }^{27} \mathrm{Al}$ NMR (A1 \%) } \\
\hline & & & $\mathrm{A} 1_{\mathrm{a}}$ & $\mathrm{A} 1_{\mathrm{b}}$ & $\mathrm{A} 1_{\mathrm{c}}$ & $\mathrm{A} 1_{\mathrm{m}}$ & $\mathrm{A} 1_{13}$ & $\mathrm{~A} 1_{\mathrm{u}}$ \\
\hline PAc1-1 & 1.4 & 3.8 & 42.3 & 8 & 49.7 & 38.4 & 6.8 & 54.8 \\
\hline PAC1-E & 2.1 & 4.06 & 19 & 65.8 & 15.2 & 16.6 & 60 & 23.4 \\
\hline
\end{tabular}




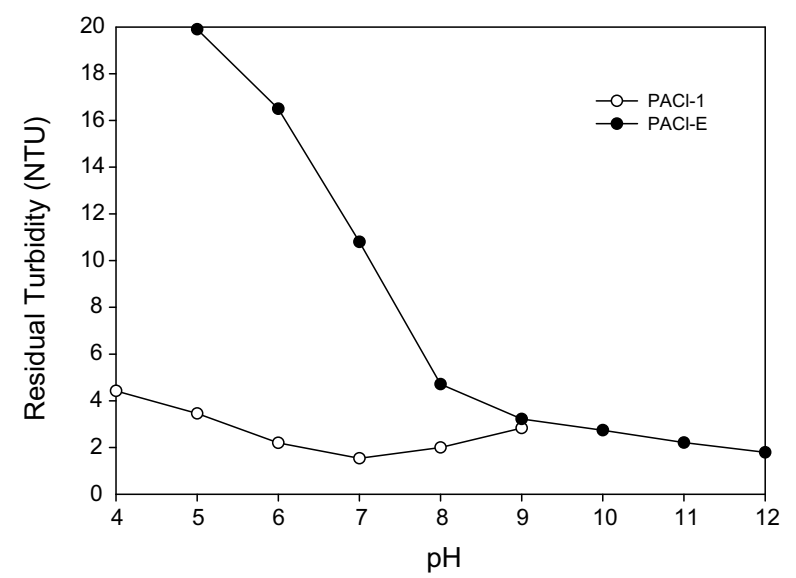

Fig. 1. $\mathrm{pH}$ effect on turbidity removal with $\mathrm{PACl}-1$ and PACl-E coagulation at dosage of $2.5 \mathrm{mg} \mathrm{l}^{-1}$ as $\mathrm{Al}$ for the simulated water with 250 NTU.

subsequently in the jar tests to evaluate the optimum $\mathrm{pH}$ for both PACl-1 and PACl-E coagulation. The RT of PACl-1 and PACl-E coagulation at various $\mathrm{pH}$ values are shown in Fig. 1. A marked difference between the two coagulants was observed. Fig. 1 shows that the optimum $\mathrm{pH}$ for PACl-1 coagulation occurred around $\mathrm{pH} 7$, which implies that sweep flocculation (enmeshment) by $\mathrm{Al}(\mathrm{OH})_{3}$ was probably the principal coagulation mechanism of PACl-1. For PACl-E coagulation, the RT decreased continuously with increasing $\mathrm{pH}$. Since the coagulation performance is directly affected by the effective $\mathrm{Al}$ species, the $\mathrm{pH}$ effect on coagulation may be explained by its effect on $\mathrm{Al}$ speciation.

\section{3. pH effect on Al speciation of PACl-1 and PACl-E during coagulation}

The hydrolysis products of aluminium coagulants are significantly affected by the $\mathrm{pH}$ of the solution. Both $\mathrm{Al}$ speciation and solubility of the polyaluminium coagulants vary with $\mathrm{pH}$ (Pernitsky and Edzwald, 2003). Al speciation of PACl-1 and PACl-E at various $\mathrm{pH}$ values, as measured by Ferron assay, is shown in Fig $2 \mathrm{a}$ and $\mathrm{b}$, respectively. A distinct difference was observed. For PACl-1, the $\mathrm{Al}_{\mathrm{a}}$ dropped sharply in the range of $\mathrm{pH} 4-5$. Very little monomeric $\mathrm{Al}\left(\mathrm{Al}_{\mathrm{a}}\right)$ was detected at neutral $\mathrm{pH}$, but concentrations then rose rapidly at high $\mathrm{pH}$. The disappearance of $\mathrm{Al}_{\mathrm{a}}$ at neutral $\mathrm{pH}$ was compensated by the rise in $\mathrm{Al}_{\mathrm{b}}$ and $\mathrm{Al}_{\mathrm{c}}$, in which the $\mathrm{Al}_{\mathrm{c}}$ was substantially more than $\mathrm{Al}_{\mathrm{b}}$. In contrast, $\mathrm{pH}$ had little effect on any of the three species of PACl-E. The most dramatic observation was that the $\mathrm{Al}_{\mathrm{a}}$ of PACl-E stayed very low, especially at neutral $\mathrm{pH}$, while the $\mathrm{Al}_{\mathrm{b}}$ content was extremely high, ranging from $60 \%$ to $70 \%$. Only a little $\mathrm{Al}_{\mathrm{a}}$ of PACl-E transformed into $\mathrm{Al}_{\mathrm{b}}$ at neutral $\mathrm{pH}$. In addition, $\mathrm{Al}_{\mathrm{c}}$ content of $\mathrm{PACl}-\mathrm{E}$ decreased slightly in the basic $\mathrm{pH}$ region. The study also indicated a discrepancy between the stability of the $\mathrm{Al}_{\mathrm{b}}$ species pre-formed before the dosing and those formed
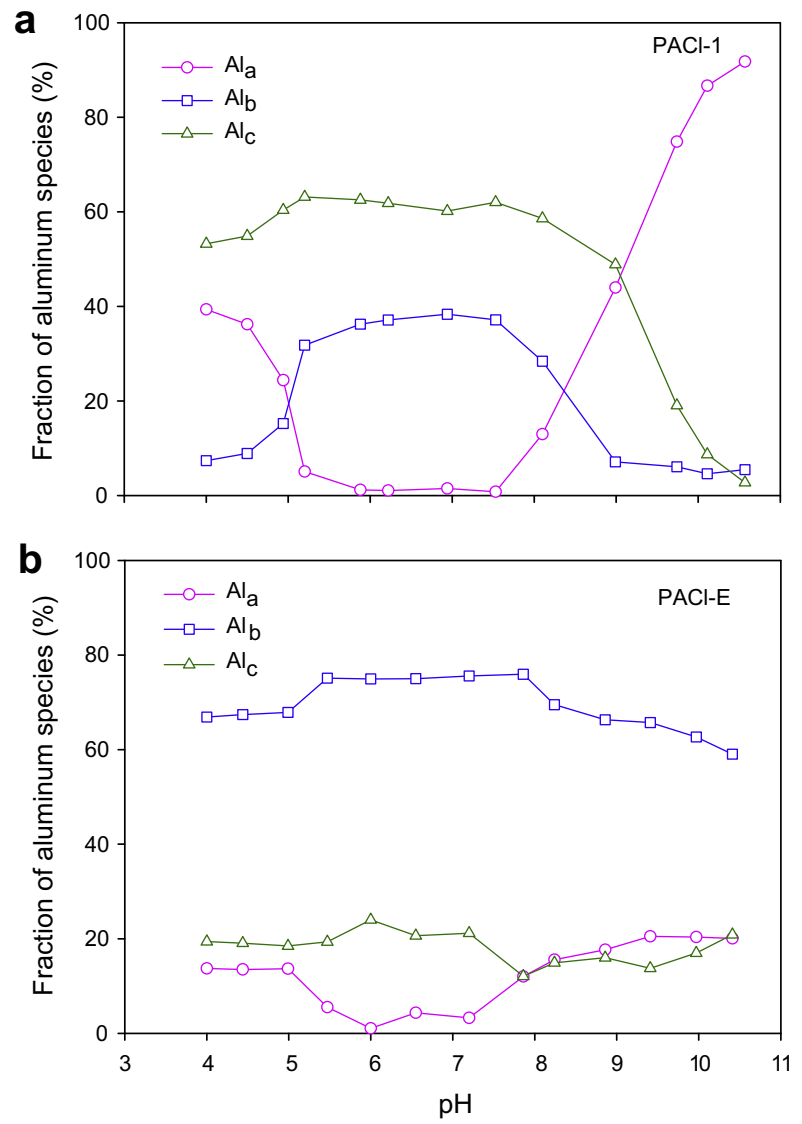

Fig. 2. Al speciation of (a) PACl-1 and (b) PACl-E under various $\mathrm{pH}$ conditions at a concentration of $5.4 \mathrm{mg} \mathrm{Al}^{-1}$.

in-situ after dosing, suggesting different $\mathrm{Al}_{\mathrm{b}}$ structures (Wang et al., 2004). Although the maximum $\mathrm{Al}_{\mathrm{b}}$ was observed at neutral $\mathrm{pH}$ for PACl-1, the in-situ formed $\mathrm{Al}_{\mathrm{b}}$ species was metastable, and thus probably transformed into $\mathrm{Al}_{\mathrm{c}}$ or another $\mathrm{Al}$ species immediately after dosing $(\mathrm{Hu}$ et al., 2006). On the contrary, the pre-hydrolyzed $\mathrm{Al}_{\mathrm{b}}$ in PACl-E remained stable with varying $\mathrm{pH}$. As a result, $\mathrm{PACl}-1$ and $\mathrm{PACl}-\mathrm{E}$ responded differently to $\mathrm{pH}$.

Study has reported that aluminium(III) species would be transformed into voluminous aluminium hydroxide $\left(\mathrm{Al}(\mathrm{OH})_{3}\right)$ at neutral $\mathrm{pH}$ (Duan and Gregory, 2003). Large amounts of $\mathrm{Al}_{\mathrm{c}}$ formed in the neutral $\mathrm{pH}$ region for PACl1 , indicating the formation of significant amount of amorphous aluminium hydroxide $\left(\mathrm{Al}(\mathrm{OH})_{3}\right)$, and consequently the occurrence of precipitation. In addition, because the in-situ formed $\mathrm{Al}_{\mathrm{b}}$ that occurred in the neutral $\mathrm{pH}$ region can quickly transform into $\mathrm{Al}_{\mathrm{c}}, \mathrm{Al}_{\mathrm{c}}$ dominated over PACl-1 coagulation at neutral $\mathrm{pH}$. As a result, enmeshment by amorphous aluminium hydroxide was responsible for the turbidity removal by $\mathrm{PACl}-1$ at neutral $\mathrm{pH}$, as seen in Fig. 2. On the other hand, because the $\mathrm{Al}_{13}$ content of PACl-E consistently exceeded $60 \%$ of total Al concentration throughout the entire $\mathrm{pH}$ range studied, charge neutralization most likely played a significant role in turbidity removal. However, maximum turbidity removal was observed at alkaline $\mathrm{pH}$, which could be explained 
by the effect of $\mathrm{Al}$ aggregation on particle-aggregation. $\mathrm{Al}$ aggregates formed at various $\mathrm{pH}$ values differ in electrophoretic mobility and charge. Studies have suggested that polymeric aluminium species aggregate and precipitate above pH 7.5 (Van Benschoten and Edzwald, 1990; Wang et al., 2004). Although the aggregation and precipitation of $\mathrm{Al}_{13}$ occurred above $\mathrm{pH} 6$, and the charge of aggregated $\mathrm{Al}_{13}$ became weak at such condition (Furrer et al., 1992), previous study has shown that $\mathrm{Al}_{13}$ still has some charge neutralization ability to aggregate particles (Chen et al., 2006). Thus, the PACl-E aggregates containing voluminous $\mathrm{Al}_{13}$ possibly remain weakly positively charged in the basic $\mathrm{pH}$ region to induce an electrostatic patch during coagulation (Wang et al., 2002), which promotes more turbidity removal in the basic $\mathrm{pH}$ region. As such, the coagulation of PACl-E is mainly dictated by charge neutralization.

\subsection{Effect of turbidity on PACl-1 and PACl-E coagulation}

To examine the efficiency of PACl-1 and PACl-E coagulation on highly turbid water, various dosages of PACl-1 and PACl-E were applied on both simulated and natural water. The turbidity ranged from 50 to 5300 NTU for simulated water and from 450 to 10000 NTU for natural water. The major Al speciation of PACl-1 and PACl-E at $\mathrm{pH} 7$ and $\mathrm{pH}$ 8, is shown in Fig. 2. Coagulation efficiency is strongly dependent on the speciation of aluminium coagulants. Moreover, $\mathrm{pH}$ can significantly affect the surface charge of turbid particles as well as the speciation of aluminium coagulants during hydrolysis. In order to understand the effects of major speciation of PACl-1 and $\mathrm{PACl}-\mathrm{E}$ on the coagulation of high turbidity water, $\mathrm{pH}$ values were controlled at 7 and 8 for PACl-1 and PACl-E coagulation, respectively, for the study.

The RT for simulated water and natural water was measured to determine the ability for particle removal, as presented in Figs. 3 and 4, respectively. The variation of zeta potential (ZP) with coagulation dosage was also monitored for simulated water, as shown in Fig. 3. For both PACl-1 and $\mathrm{PACl}-\mathrm{E}$, the $\mathrm{ZP}$ of the particles and turbidity removals increased with increasing dosage. The increase in $\mathrm{ZP}$ by PACl-E was more significant than that of PACl-1. At low turbidity, e.g., $50 \mathrm{NTU}$, as seen in Fig. 4a, PACl-1 was more effective in particle removal even though PACl$\mathrm{E}$ was more efficient in charge neutralization of the particles. The difference became insignificant when the original turbidity of the water was increased. At 5300 NTU, PACl-E was superior to PACl-1 in turbidity removal,
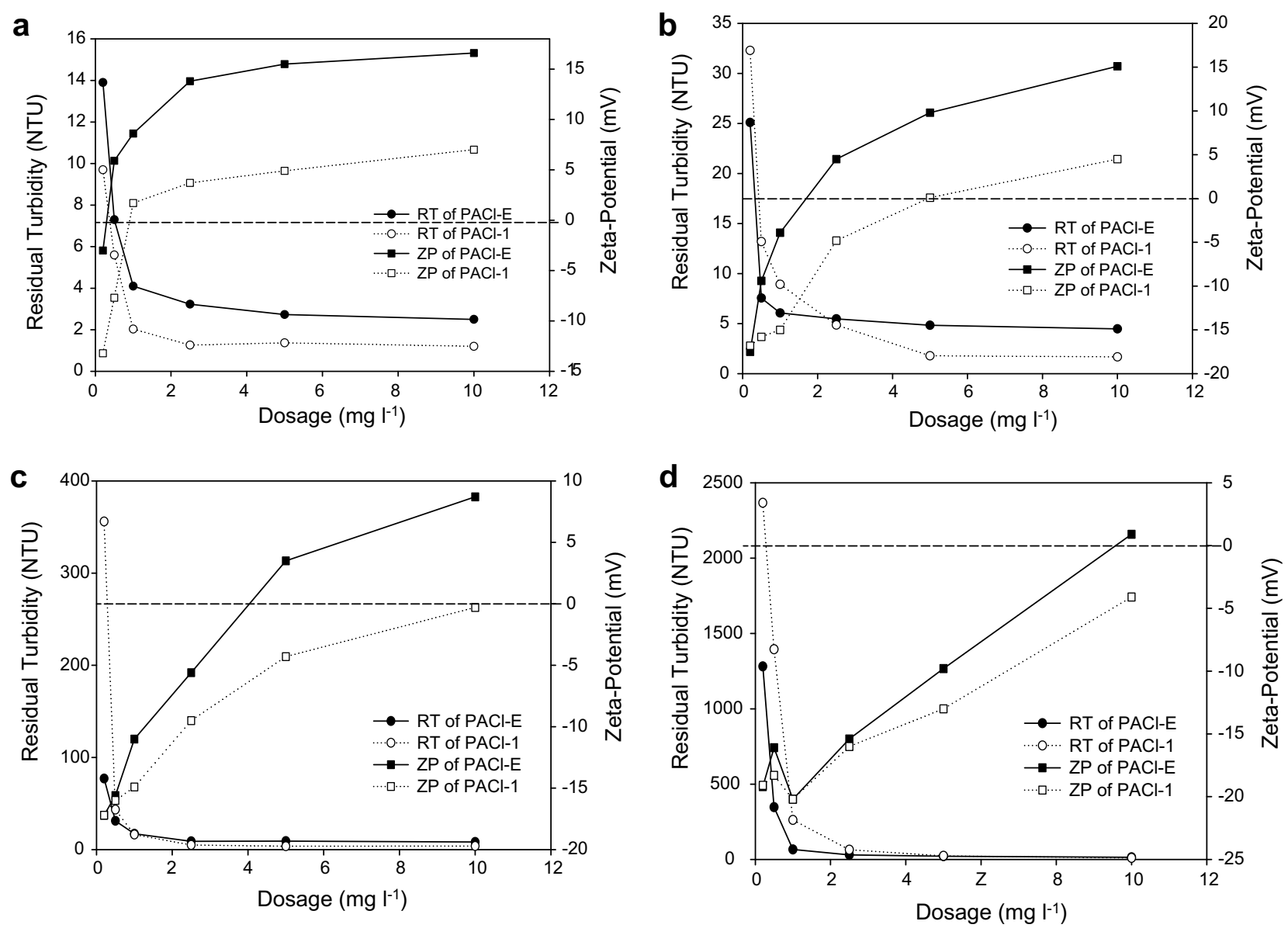

Fig. 3. Residual turbidity (RT) and zeta-potential (ZP) changes of simulated water at various coagulant dosages. The pH was controlled at 7 for PACl-1 and 8 for PACl-E, and the original turbidities were (a) 50 NTU, (b) 1000 NTU, (c) 2500 NTU and (d) 5300 NTU. 

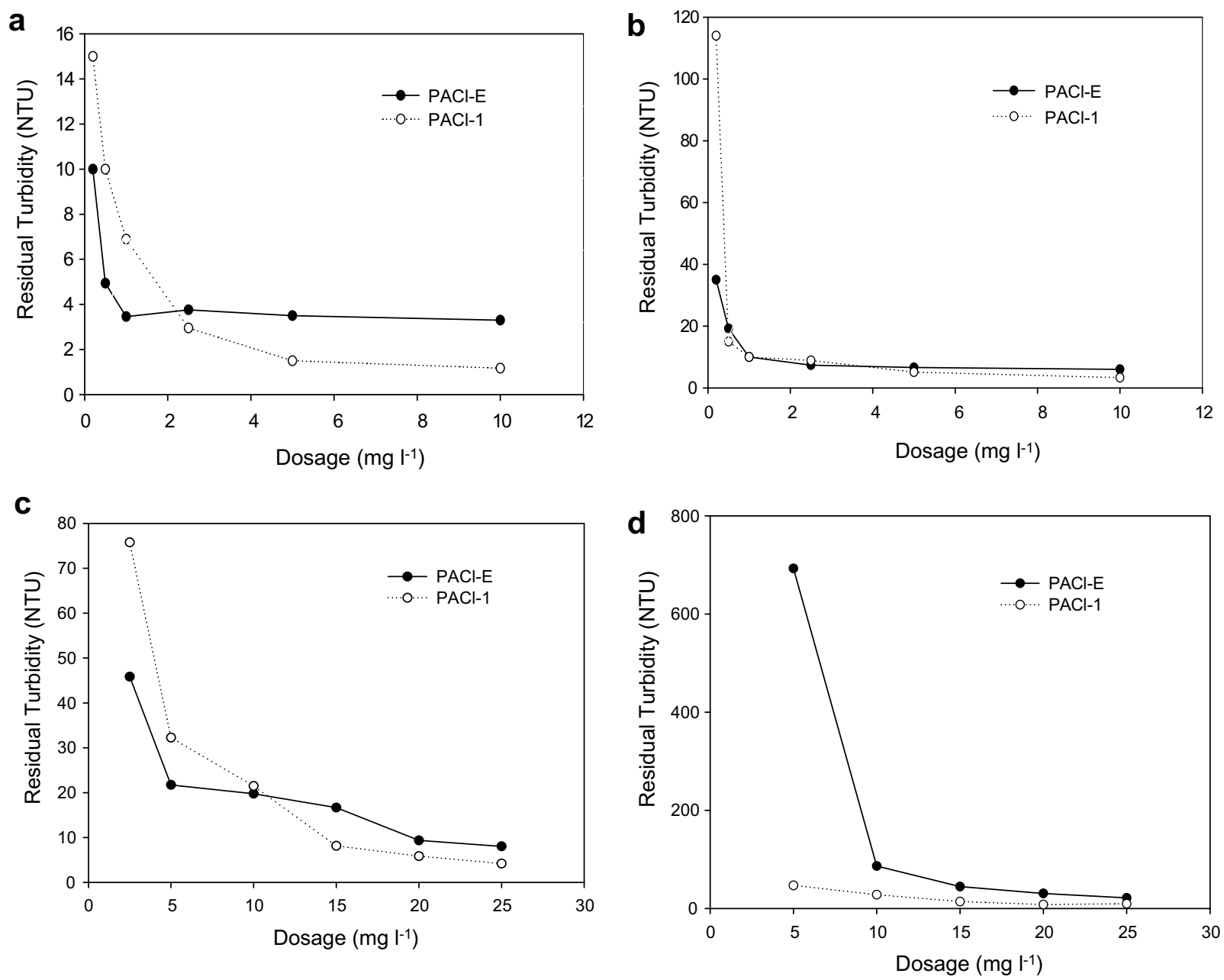

Fig. 4. Variations of residual turbidity of natural water at various coagulant dosages. The $\mathrm{pH}$ was controlled at 7 for PACl-1 and 8 for PACl-E, and the original turbidities were (a) $450 \mathrm{NTU}$, (b)2550 NTU, (c) $5000 \mathrm{NTU}$ and (d) $10000 \mathrm{NTU}$.

especially at low dosage. At low turbidity, large particleaggregation was limited due to an insufficient number of particles, despite the strong charge neutralization of PACl-E. Because of the increase of turbidity, the collision efficiency between particles during the coagulation process will increase. An increase of collision efficiency will improve the particle-aggregation induced by charge neutralization or electrostatic patch (Gregory, 1973). As a result, PACl-E containing a large amount of $\mathrm{Al}_{13}$ can aggregate particles by charge neutralization (or electrostatic patch) at dosage less than $2 \mathrm{mg}^{-1}$ even as turbidity is increased continuously. A similar result was observed with natural highly turbid water.

On the other hand, effective turbidity removal also occurred at high dosage in which the zeta potential of suspended particles was high positive, which is similar to the results of previous research (Chen et al., 2006). Furrer et al. (1992) have suggested that the polymeric aluminium species would aggregate and precipitate above $\mathrm{pH} 6$. Study also has indicated that $\mathrm{Al}_{13}$ could be transformed into linear $\mathrm{Al}_{13}$ aggregates by maintaining a total high aluminium concentration (Bottero et al., 1987). In our study, because the PACl-E coagulation was conducted at $\mathrm{pH} 8$, the $\mathrm{Al}_{13}$ aggregates can occur when high PACl-E dosage was applied. As a result, PACl-E could induce particle-aggregation by interparticle bridging at a higher dosage even though the zeta potential of suspended particles was high positive.

The results with natural highly turbid water are depicted in Fig. 4, in which the turbidity spanned from 450 to 10000 NTU. For turbidity levels up to 5000 NTU, PACl-E was generally more efficient than PACl-1, particularly at low dosage, similar to the previous result with simulated water (Fig. 3). At 10000 NTU, this advantage was overturned. Studies have reported that the organic matter in water would preferentially react with $\mathrm{Al}_{13}$ and decompose the structure of the cationic polymer $\mathrm{Al}_{13}$ (Vilge-Ritter et al., 1999; Liu et al., 1999b; Masion et al., 2000; Exall and vanLoon, 2003; Kazpard et al., 2006). The strong charge neutralization ability of PAC-E was deprived in the highly turbid natural water at $10000 \mathrm{NTU}$ due to the high organic content, as suggested in Table 1 . Because the $\mathrm{Al}_{13}$ species is critical in removing particles from the high turbidity water, as demonstrated in Fig. 3, the occurrence of large amounts 
of organic matter in the natural water interfered with the coagulation efficiencies of PACl-E. This phenomenon disappeared when the dosage was increased. Moreover, since coagulation by PACl-1 mostly depends upon enmeshment at neutral $\mathrm{pH}$, extremely high turbidity (10000 NTU) assisted in particle removal by enmeshment, even at low dosage. Studies have suggested that in the presence of organic matter, $\mathrm{Al}(\mathrm{III})$ does not hydrolyze into $\mathrm{Al}_{13}$ at neutral $\mathrm{pH}$. Conversely, it transforms into $\mathrm{Al}(\mathrm{OH})_{3}$, which then removes organic matter by adsorption and precipitation (Huang and Shiu, 1996). Thus, particle removal during PACl-1 coagulation was somewhat insensitive to dosage at neutral $\mathrm{pH}$ for the highly turbid water containing a high organic matter load. Another study has also shown that $\mathrm{PACl}$ can simultaneously remove turbidity, as well as humic acid from highly turbid water at neutral $\mathrm{pH}$ (Annadurai et al., 2004), which supports the result of Fig. 4d.

\subsection{Dewaterability of sludge from PACl-1 and PACl-E coagulation}

The sludge characteristics depend on the mechanisms of coagulation. Study has suggested that sludge formed from
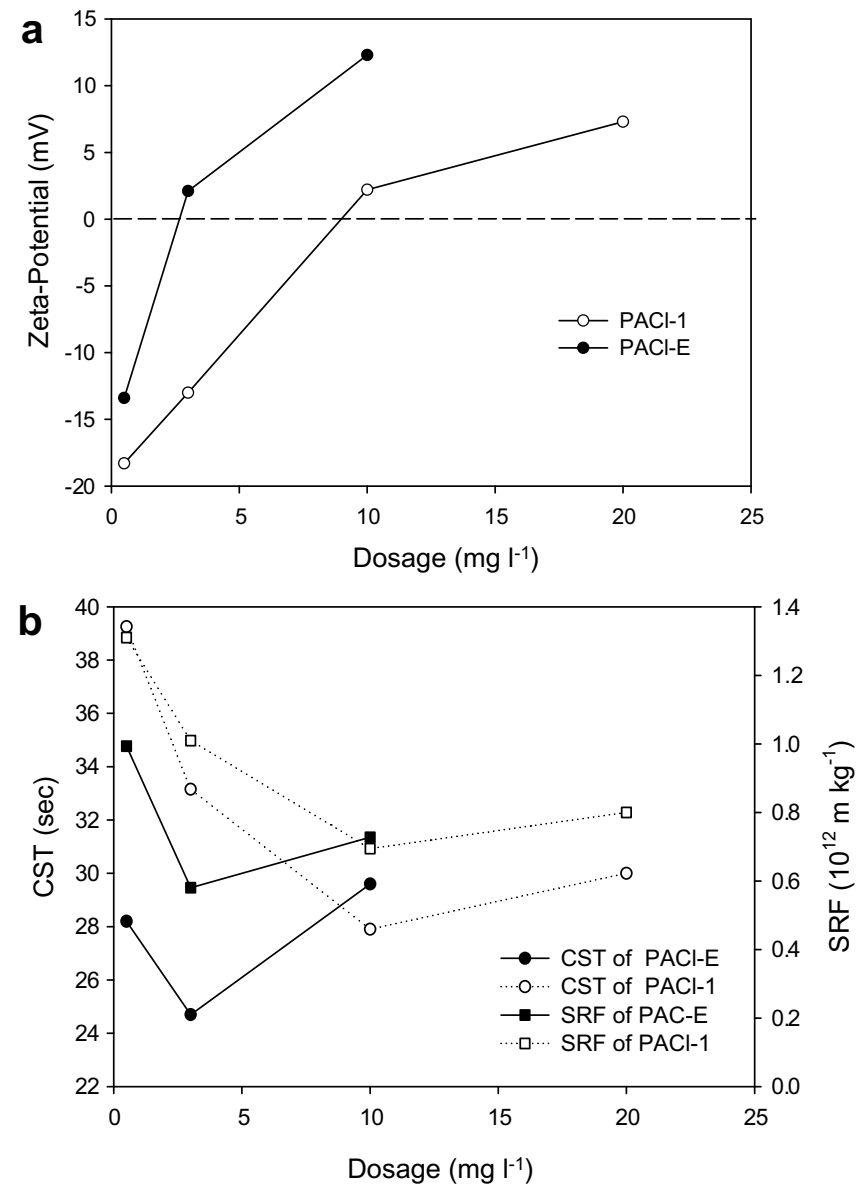

Fig. 5. Dosage effect on the sludge dewaterability of PACl-1 and PACl-E coagulation with natural water at 1300 NTU: (a) ZP and (b) sludge dewaterability. charge neutralization is more easily dewatered ( $\mathrm{Wu}$ and $\mathrm{Wu}, 2001)$. Capillary suction time (CST) and specific resistance filtration (SRF) were determined to reflect the dewatering of sludge, which is presented in Fig. 5, along with the ZP at various coagulant dosages. Natural water at 1300 NTU was the test water. A marked difference was observed between the dewaterability of PACl-1 and PACl-E sludge. Both CST and SRF indicated that sludge from PACl-E has higher sludge dewaterability due to the coagulation mechanism of charge neutralization, attributed to high $\mathrm{Al}_{13}$ content. The dosages for the optimum dewatering of the sludge from both PACl-1 and PACl-E coagulations coincide with the dosages at which the zeta potentials of the both samples were around zero. Since enmeshment is the predominant mechanism for PACl-1 coagulation, the sludge thus formed was harder to be dewatered.

\section{Conclusions}

Coagulation efficiency of $\mathrm{PACl}$ from different preparations may vary substantially. For PACl-E, the coagulation efficiency increases with increasing $\mathrm{pH}$, while the optimum operational $\mathrm{pH}$ for $\mathrm{PACl}-1$ remains around neutral. The PACl-E has a higher $\mathrm{Al}_{13}$ content which remains fairly constant at various $\mathrm{pH}$ conditions. Al speciation of PACl-1 varies significantly with $\mathrm{pH}$ especially the $\mathrm{Al}_{\mathrm{a}}$ (monomeric $\mathrm{Al})$ and $\mathrm{Al}_{\mathrm{c}}\left(\mathrm{Al}(\mathrm{OH})_{3}\right)$ contents. Coagulation with $\mathrm{PACl}-$ $\mathrm{E}$ in the basic $\mathrm{pH}$ region at low dosage is due to charge neutralization or electrostatic patch, while that of PACl-1 relies mostly on sweep flocculation (enmeshment). PACl$\mathrm{E}$ is superior to $\mathrm{PACl}-1$ in turbidity removal for natural highly turbid water up to 5000 NTU. However, a sufficient number of particles is necessary to promote large particle aggregation during PACl-E coagulation. The presence of high organic content in highly turbid water can disturb the charge neutralization ability of PACl-E. Sludge produced from charge neutralization of $\mathrm{PACl}-\mathrm{E}$ coagulation is more easily dewatered than that from the enmeshment of PACl-1.

\section{Acknowledgements}

The authors would like to extend their appreciation to Mr. Wei-Hong Chen of the Institute of Environmental Engineering of NCTU for his excellent laboratory work. Thanks also go to ITRI for the financial support for this project and Taiwan Water Corporation for assistances. The authors are grateful to Prof. Jiu-Hui Qu and Prof. Z.J. Deng in RCEES-CAS (China) for providing the PACl-E powder and assisting in NMR measurements.

\section{References}

Annadurai, G., Sung, S.S., Lee, D.J., 2004. Simultaneous removal of turbidity and humic acid from high turbidity storm water. Adv. Environ. Res. 8, 713-725. 
Bertsch, P.M., 1987. Conditions for $\mathrm{Al}_{13}$ polymer formation in partially neutralized aluminium solutions. Soil Sci. Soc. Am. J. 51, 825-828.

Bottero, J.Y., Axelos, M., Tchoubar, D., Cases, J.M., Fripiat, J.J., Fiessinger, F., 1987. Mechanism of formation of aluminium trihydroxide form Keggin $\mathrm{Al}_{13}$ polymers. J. Colloid Interf. Sci. 117, 47-57.

Chen, Z.Y., Fan, B., Peng, X.J., Zhang, Z.G., Fan, J.H., Luan, Z.K., 2006. Evaluation of $\mathrm{Al}_{30}$ polynuclear species in polyaluminium solutions as coagulant for water treatment. Chemosphere 64, 912-918.

Di Bernardo, D., Di Bernardo, L., 2006. Performance of two-stage filtration system for treating high turbidity water. J. Water Suppl.: Res. Technol--AQUA 557, 499-515.

Duan, J., Gregory, J., 2003. Coagulation by hydrolyzing metal salts. Adv. Colloid Interf. Sci., 475-502.

Exall, K.N., VanLoon, G.W., 2003. Effects of raw water conditions on solution-state aluminium speciation during coagulant dilution. Water Res. 37, 3341-3350.

Fang, S., Fu, L., 2004. Theory and Technology of High Turbidity Water Supply. Chemical Industries Publication, Beijing.

Furrer, G., Ludwig, C., Schindler, P.W., 1992. On the chemistry of the Keggin $\mathrm{Al}_{13}$ polymer. I. Acid-base properties. J. Colloid Interf. Sci. $149,56-67$.

Gao, B.Y., Chu, Y.B., Yue, Q.Y., Wang, B.J., Wang, S.G., 2005. Characterization and coagulation of a polyaluminium chloride (PAC) coagulant with high $\mathrm{Al}_{13}$ content. J. Environ. Manage. 76, 143-147.

Gregory, J., 1973. Rates of flocculation of latex particles by cationic polymers. J. Colloid Interf. Sci. 42, 448-456.

Hu, C.Z., Liu, H.J., Qu, J.H., 2005. Preparation and characterization of polyaluminium chloride containing high content of $\mathrm{Al}_{13}$ and active chlorine. Colloid Surface A 260, 109-117.

Hu, C.Z., Liu, H.J., Qu, J.H., Wang, D.S., Ru, J., 2006. Coagulation behavior of aluminium salts in eutrophic water: Significance of $\mathrm{Al}_{13}$ species and pH control. Environ. Sci. Technol. 40, 325-331.

Huang, C.P., Shiu, H.L., 1996. Interactions between alum and organics in coagulation. Colloid Surface A 113, 155-163.

Huang, L., Wang, D.S., Tang, H.X., Wang, S., 2006. Separation and purification of nano-Al $\mathrm{l}_{13}$ by UF method. Colloid Surface A 275, 200 208.

Kan, C.C., Huang, C.P., Pan, J.R., 2002. Coagulation of high turbidity water: the effect of rapid mixing. J. Water Suppl.: Res. Technol. -AQUA 51, 77-85.

Kazpard, V., Lartiges, B.S., Frochot, C., d'Espinose de la Caillerie, J.B., Viriot, M.L., Portal, J.M., Görner, T., Bersillon, J.L., 2006. Fate of coagulant species and conformational effects during the aggregation of a model of a humic substance with $\mathrm{Al}_{13}$ polycations. Water Res. 40, 1965-1974.

Kloprogge, J.T., Seykens, D., Jansen, J.B.H., Geus, J.W., 1992. A ${ }^{27}$ Al nuclear magnetic resonance study. J. Non-Cryst. Solid 142, 94-102.
Kwon, S.B., Ahn, H.W., Ahn, C.J., Wang, C.K., 2004. A case study of dissolved air flotation for seasonal high turbidity water in Korea. Water Sci. Technol. 50 (12), 245-253.

Lin, W.W., Sung, S.S., Chen, L.C., Chung, H.Y., Wang, C.C., Wu, R.M., Lee, D.J., Huang, C.P., Juang, R.S., Peng, X.F., Chang, H.L., 2004. Treating high-turbidity water using full-scale floc blanket clarifiers. J. Environ. Eng. 130, 1481-1487.

Liu, G.G., Qu, J.H., Tang, H.G., 1999a. The electrochemical production of highly effective polyaluminium chloride. Water Res. 33, 807-813.

Liu, X.Q., Chen, Z.L., Yang, X.H., 1999b. Spectroscopic study of aluminium speciation in removing humic substances by Al coagulation. Water Res. 33, 3271-3280.

Masion, A., Vilge-Ritter, A., Rose, J., Stone, W.E.E., Teppen, B.J., Rybacki, D., Bottero, J., 2000. Coagulation-flocculation of natural organic matter with $\mathrm{Al}$ salts: speciation and structure of the aggregates. Environ. Sci. Technol. 34, 3242-3246.

Parker, D.R., Bertsch, P.M., 1992. Identification and quantification of the $\mathrm{Al}_{13}$ tridecameric polycation using ferron. Environ. Sci. Technol. 26, 913-914.

Pernitsky, D.J., Edzwald, K., 2003. Solubility of polyaluminium coagulants. J. Water Suppl.: Res. Technol.-AQUA 52, 395-406.

$\mathrm{Qu}$, J.H., Liu, H.J., 2004. Optimum conditions for $\mathrm{Al}_{13}$ polymer formation in PACl preparation by electrolysis process. Chemosphere 55, 51-56.

Shi, B.Y., Li, G.H., Wang, D.S., Tang, H.X., 2007. Separation of $\mathrm{Al}_{13}$ from polyaluminium chloride by sulfate precipitation and nitrate metathesis. Sep. Purif. Technol. 54, 88-95.

Smith, R.W., 1971. Relations among equilibrium and nonequilibrium aqueous species of aluminium hydroxy complexes. Am. Chem. Soc. Adv. Chem. Ser. 106, 250-279.

Van Benschoten, J.V., Edzwald, J.K., 1990. Chemical aspects of coagulation using aluminium slats-I. Hydrolytic reactions of alum and polyaluminum chloride. Water Res. 24, 1519-1526.

Vilge-Ritter, A., Masion, A., Boulange, T., Rybacki, D., Bottero, J., 1999. Removal of organic matter by coagulation-flocculation: a pyrolysisGC-MS study. Environ. Sci. Technol. 33, 3027-3032.

Wang, W.Z., Hsu, P.H., 1994. The nature of polynuclear OH-Al complexes in laboratory-hydrolyzed and commercial hydroxyalumin solutions. Clay Clay Miner. 42, 356-368.

Wang, D.S., Tang, H.X., Gregory, J., 2002. Relative importance of charge neutralization and precipitation on coagulation of kaolin with $\mathrm{PACl}$ : effect of sulfate ion. Environ. Sci. Technol. 36, 1815-1820.

Wang, D.S., Sun, W., Xu, Y., Tang, H.X., Gregory, J., 2004. Speciation stability of inorganic polymer flocculant-PACl. Colloid Surface A. 243, $1-10$.

$\mathrm{Wu}$, C.C., Wu, J.J., 2001. Effect of charge neutralization on the dewatering performance of alum sludge by polymer conditioning. Wat. Sci. Technol. 44 (10), 315-319. 